\title{
PENDIDIKAN ISLAM PERSPEKTIF FAZLUR RAHMAN
}

\author{
Muhammad Fahmi \\ (Dosen UIN Sunan Ampel; juga STAI Taruna Surabaya)
}

\begin{abstract}
Abstrak:
Fazlur Rahman terkenal sebagai tokoh neo-modernisme karena berusaha melakukan modernisasi pendidikan Islam dengan tidak melupakan warisan klasik umat Islam. Dia mengusulkan bahwa orientasi pendidikan Islam harus mengarah kepada kebutuhan di dunia dan akhirat. Dia juga tidak setuju dengan adanya dikotomi ilmu agama dan umum. Harus ada upaya integrasi antara ilmu agama dan umum, karena pada dasarnya ilmu itu utuh dan bersumber dari Allah SWT. Dia juga menyarankan agar ada upaya peningkatan kualitas pendidik Muslim, perhatian khusus terhadap peserta didik yang berbakat, dan pemenuhan sarana prasarana pendidikan yang memadai. Ide-ide Rahman mengenai pendidikan Islam termasuk dalam kategori kontekstual. Ini menunjukkan bahwa dalam mengemukakan ide-idenya, Rahman mendasarkannya pada pengalaman empirik dan pengamatan yang realistis. Oleh karena itu, tidaklah basi jika menerapkan ide-ide Rahman dalam konteks pendidikan Islam dewasa ini. Pisau analisis yang dipakai Rahman dalam mengkaji pendidikan Islam pada masanya, kiranya dapat dipakai sebagai pisau analisis dalam mengkaji pendidikan Islam kontemporer. Meski begitu, karena masa hidup Rahman berbeda dengan masa hidup umat Islam sekarang -dalam konteks sosial, maka perlu diberikan nilai kritis-transformatif bagi ide-ide Rahman sebelum diterapkan dalam konteks kekinian.
\end{abstract}

Kata Kunci: Fazlur Rahman dan Pendidikan Islam 
Muhammad Fahmi

\section{A. Pendahuluan}

Dalam diskursus perkembangan pemikiran Islam, muncul berbagai isu ke permukaan tentang terjadinya akumulasi krisis pendidikan di dunia Islam. Sebagaimana dikemukakan oleh Ismail Raji al-Faruqi, ${ }^{1}$ bahwa keadaan pendidikan di dunia Islam adalah yang terburuk, sehingga umat Islam menjadi sangat lemah. Senada dengan itu, Khursid Ahmad $^{2}$ mengemukakan bahwa di antara persoalan terbesar yang dihadapi dunia Islam dewasa ini adalah persoalan makin memburuknya pendidikan, padahal masa depan dunia Islam akan sangat bergantung pada bagaimana kinerja dunia pendidikan. Realitas ini menunjukkan bahwa pendidikan yang selama ini dilaksanakan oleh umat Islam mengalami sesuatu yang "tidak beres", baik dari segi konsep maupun aktualisasinya.

Abu A'la al-Maududi $^{3}$ mengemukakan bahwa pendidikan di dunia Islam hanya dibangun atas romantisme masa lalu, tanpa memerhatikan realitas perkembangan modernitas masyarakat Muslim, sehingga pendidikan di dunia Islam stagnan dan tidak adaptif serta responsif dengan perkembangan masyarakat modern. Abdurrahman al-Nahlawi ${ }^{4}$ menyatakan bahwa telah terjadi kesalahan metodologis dalam pelaksanaan pendidikan Islam, sehingga pendidikan Islam

\footnotetext{
${ }^{1}$ Ismail Raji al-Faruqi, Islamisasi Ilmu Pengetahuan: Prinsip-Prinsip dan Rencana Kerja, terj. Anas Mahyudin (Bandung: Pustaka, 1984), 12.

2 Machnun Husein, Pendidikan Islam dalam Lintasan Sejarah (Yogyakarta: Nur Cahaya, 1983), ix.

3 Abu A'la al-Maududi, Manhaj Jadid li Tarbiyah wa Ta'lim, terj. Judi al-Falasani (Solo: CV. Ramadani, 1991).

4 Abdurrahman al-Nahlawi, Ushul al-Tarbiyah al-Islamiyyah wa Asalibuha (Damsyik: Dar al-Fikr).
}

Jurnal Pendidikan Agama Islam Volume 02 Nomor 02 November 2014

Hal $274-298$ 
mengalami kemunduran. Fadlil al-Jamali ${ }^{5}$ menegaskan bahwa pendidikan Islam kurang menempatkan manusia sebagai subjek didik yang harus diberdayakan, manusia hanya dipandang sebagai objek pendidikan semata. Demikian juga, Syed Naquib al-Attas ${ }^{6}$ menyatakan bahwa pendidikan di dunia Islam tidak dirumuskan dan direncanakan secara sistematis dan holistik, sehingga wajar bila konsep pendidikan terasa bias aplikatif.

Apabila dicermati dari berbagai kritik yang dikemukakan oleh para intelektual Muslim terhadap pendidikan Islam sebagaimana dikemukakan di atas, dapat disimpulkan bahwa krisis yang dialami dunia pendidikan Islam tidak lain disebabkan oleh adanya kesalahan paradigmatik pada bangunan ilmu pendidikan, sehingga pada gilirannya berimplikasi pada adanya bias filosofis dan empirik pendidikan Islam. Kesalahan mendasar para intelektual Muslim, yang kemudian berakibat pada kesalahan paradigmatik dalam membangun konsep pendidikan adalah adanya kesalahan mendasar dalam memandang hakikat manusia. Manusia sering diperlakukan sebagai objek pendidikan dan dipandang secara mekanis. Padahal, manusia harus diposisikan sebagai subjek pendidikan yang dinamis.

Di samping itu, bila mencermati produk pemikiran pendidikan Islam yang berkembang, maka akan terlihat secara riil bahwa konsep pendidikan yang dikembangkan lebih cenderung bersifat materialistik-intelektualistik, jauh dengan nilai-nilai spiritual-religius dan moralitas. $^{7}$ Realitas ini

${ }^{5}$ Fadlil al-Jamali, Menerabas Krisis Pendidikan Dunia Islam, terj. Muzayin Arifin (Jakarta: Golden Terayon Press, 1988).

6 Syed Muhammad al-Nuqaib al-Attas, Islam dan Sekularisme, terj. Karsidjo Djojosuwarno (Bandung: Pustaka, 1981).

7 Banyak kritik yang diajukan oleh para intelektual Muslim mengenai konsep pendidikan yang kurang diarahkan pada aspek spiritual-religius. Naquib al- 
berimplikasi pada suatu pandangan, bahwa pendidikan hanya menyentuh segi kognitif atau intelektualitas saja tanpa memperhatikan aspek moralitas atau budi pekerti, bahkan dalam tradisi pemikiran filsafat Barat, spiritualitas diidentikkan dengan rasionalitas atau intelektualitas, sehingga pendidikan diidentikkan dengan pengembangan rasio atau intelek saja. Proses pendidikan hanya difahami dan diorientasikan pada transfer of knowledge, sementara transfer of value atau transfer of ethic diabaikan. ${ }^{8}$ Oleh karenanya, pendidikan sering menghasilkan manusia yang cerdas secara intelektual, tetapi kering dari nilai (moral).

Di sisi lain, kritik tajam terhadap pendidikan Islam juga dikemukakan oleh Fazlur Rahman, seorang intelektual Muslim Pakistan yang populer di kalangan ilmuwan Barat dan Timur karena ide-ide segarnya. Rahman ${ }^{9}$ menyatakan, bahwa strategi pendidikan Islam selama ini tidak benar-benar diarahkan pada

Attas mengemukakan bahwa untuk menghindari agar pendidikan tidak hanya mengarah pada intelektualisme, maka pendidikan harus dibahsakan dengan istilah al-ta'dib, dan tidak sekedar al-ta'lim atau al-tarbiyah. Senada dengan alAttas, Athiyah al-Abrasyi mengidentikkan pendidikan Islam dengan pendidikan moral atau akhlaq (al-tarbiyah al-Akhlaqiyah). Lihat Syed Muhammad Naquib al-Attas, Aims and Objective of Islam Education (Jeddah: King Abdul Azis University, 1979), 5-6. Bandingkan dengan Muhammad Athiyah Al-Abrasyi, AlTarbiyah al-Islamiyah (Mesir: Dar al-Fikr, 1970), 1.

8 Hasan Langgulung mencermati bahwa bila pendidikan hanya melakukan transfer of knowledge saja, maka pendidikan itu hanya menjalankan sebagian kecil dari fungsi pendidikan Islam. Menurutnya, pendidikan harus menjalankan tiga fungsi sekaligus. Pertama, menyiapkan generasi muda untuk memegang peran-peran tertentu dalam masyarakat di masa mendatang. Kedua, mentransfer (memindahkan) pengetahuan sesuai dengan peranan yang diharapkan. Ketiga, mentransfer nilai-nilai moral agama. Dalam konteks ini pendidikan tidak hanya sekedar transfer of knowledge, tetapi sekaligus transfer of value atau transfer of moral, dan inilah yang manjadi inti substansi pendidikan Islam. Lihat Hasan Langgulung, Beberapa Pemikiran tentang Pendidikan Islam (Bandung: Al-Ma'arif, 1980), 92.

${ }^{9}$ Fazlur Rahman, Islam dan Modernitas: Tentang Transformasi Sosial, terj. Ahsin Muhammad (Bandung: Pustaka, 1985), 86.

Jurnal Pendidikan Agama Islam

Volume 02 Nomor 02 November 2014

Hal $276-298$ 
tujuan yang positif, tetapi lebih cenderung bersifat defensif yaitu untuk menyelamatkan fikiran kaum Muslim dari pencemaran atau kerusakan yang ditimbulkan oleh dampak gagasan-gagasan Barat yang datang melalui berbagai disiplin ilmu, terutama gagasan-gagasan yang akan meledakkan standar moralitas Islam.

Bertolak dari realitas di atas, maka menguak pemikiran pendidikan Islam dengan berbagai otokritik dan ide konstruktif-nya menjadi menarik dan bermakna serta memiliki urgensi yang tinggi, terutama sebagai ijtihad untuk ikut serta memberikan kontribusi bagi perbaikan konsep pendidikan Islam. Lebih lanjut, tulisan ini akan memakai pisau analisis Fazlur Rahman dalam mengkritisi dan upaya memperbaharui pendidikan Islam.

\section{B. Mengenal Fazlur Rahman}

Fazlur Rahman (kemudian disebut Rahman), lahir ketika anak benua Indo-Pakistan belum terpecah kedalam dua negara merdeka, tepatnya tahun 1919, di daerah Hazara, sebelah Barat Laut Pakistan. Dia dibesarkan dalam keluarga dengan tradisi madzhab Hanafi, sebuah madzhab Sunni yang lebih bercorak rasionalis dibandingkan dengan ketiga madzhab Sunni yang lain, yakni Syafi'i, Maliki, dan Hanbali. ${ }^{10}$ Dia tumbuh dan berkembang dalam tradisi pemikiran yang tidak sempit, terbukti semenjak umur belasan tahun dia telah mengembangkan pemikirannya secara bebas dan progresif.

10 M. Azhar, Fiqih Kontemporer dalam Pandangan Neomodernisme Islam (Yogyakarta: Pustaka Pelajar, 1996), 30. Lihat juga Taufiq Adnan Amal, Islam dan Tantangan Modernitas: Studi atas Pemikiran Hukum Fazlur Rahman, Cet. Ke-4 (Bandung: Mizan, 1993), 79-111. Bandingkan dengan M. Hasbi Amiruddin, Konsep Negara menurut Fazlur Rahman (Yogyakarta: UII Press, 2000), 9-30. Lihat juga Rafiq Zainul Mun'im, "Fazlur Rahman dan Tafsir Kontekstual", Wacana (Surabaya: Kopertais IV, Maret 2005), 33-38. 
Rahman mengawali pendidikan formalnya di sebuah madrasah tradisional paling bergengsi di benua Indo-Pakistan, yaitu sebuah madrasah yang didirikan oleh Muhammad Qosim Nantawi pada tahun 1867.11 Setelah itu, Rahman melanjutkan studinya di Punjab University, dan pada tahun 1942 dia telah berhasil menyelesaikan pendidikan pascasarjana-nya dalam bidang studi Sastra Arab. Dia lalu melanjutkan studinya di Lahore untuk program Ph.D, tetapi dia merasa tidak puas dengan mutu pendidikan yang ada di dalamnya, sehingga dia tidak meneruskannya, dan pada tahun 1946, dia memutuskan untuk melanjutkan studi ke Oxford University, di Inggris. Pada tahun 1950, dia berhasil meraih gelar doktor dalam bidang filsafat dari universitas tersebut dengan disertasi tentang pemikiran Ibnu Sina. ${ }^{12}$

Setelah lulus dari Oxford, Rahman menyempatkan diri untuk mengajar di dua universitas terkemuka di Eropa, yaitu Durham University di Inggris (1951-1958), dan Institut of Islamic Studies Mc Gill University di Kanada (1958-1961). Selama mengajar di kedua universitas tersebut, dia telah menerbitkan beberapa karya; baik terjemahan, suntingan, maupun karya orisinalnya, dan itu membuat namanya populer dan diakui kapasitas keilmuannya secara luas oleh sarjanasarjana Barat dan Timur. Di awal tahun 1960-an, dia memutuskan untuk kembali ke tanah airnya, Pakistan. Pada tahun 1962, dia ditunjuk sebagai Direktur Institut of Islamic Research, setelah menjabat sebagai staf senior di lembaga riset tersebut. Pada tahun 1964 dia diangkat sebagai anggota Advisory Council of Islamic Ideology pemerintah Pakistan. ${ }^{13}$

\footnotetext{
${ }^{11}$ Fazlur Rahman, Islam dan Modernitas: ...., 36-98.

12 Taufiq Adnan Amal, Islam..., Op.Cit., 81.

13 Rafiq Zainul Mun'im, "Fazlur Rahman dan Tafsir Kontekstual”, 34-35. 
Ketika menduduki jabatan strategis di kedua lembaga bergengsi tersebut di atas, Rahman mendapatkan resistensi (reaksi keras) dari kelompok ulama tradisionalis, karena menurut tradisi, orang yang berhak menduduki jabatan direktur di Institut of Islamic Research adalah ulama yang pernah mengenyam pendidikan tradisional. Oleh karena itu, pada tahun 1970 dia berhijrah ke Amerika dan menetap di sana hingga meninggal dunia pada tanggal 26 Juli 1988. Kepindahannya ke sarang orientalis itu karena oposisi yang tak sehat dari kalangan tradisionalis dan fundamentalis terhadap pemikiran-pemikirannya yang dianggap liberal dan merongrong ajaran Islam. Keadaan tersebut semakin menyadarkannya bahwa kebanyakan umat Islam, termasuk di negara kelahirannya, belum siap berada dalam atmosfir kebebasan intelektual.

Rahman termasuk ilmuwan yang sangat produktif dan progresif, dan telah banyak menghasilkan karya tulis dalam berbagai bidang keilmuan yang luas. Karya-karya yang berbentuk artikel tersebar dalam berbagai jurnal, berjumlah sekitar 75 buah, disamping 7 artikel yang dimuat dalam beberapa ensiklopedi, dan berupa review buku berjumlah 16 buah. Sementara itu, karya-karya yang berupa buku, setidaknya berjumlah 9 buah, antara lain: Avicenna's Psychology (1952), Propecy in Islam; Philosophy and Ortodoxy (1958), Avicena's de Anima; Being the Psychological Part of Kitab al-Syifa' (1959), Islamic Metodology in History (1965), Islam (1966), Philosophy of Mulla Shadra Syrazi (1976), Major Themes of the Quran (1980), Islam and Modernity; Transformation of on Intellectual Tradition (1982), dan Healt and Medicine in Islamic Tradition (1987). ${ }^{14}$

14 Rafiq Zainul Mun'im, “Fazlur Rahman dan Tafsir Kontekstual”, 36. 
Arus modernisasi yang sebagian besar meliputi mayoritas negara-negara Islam, menyebabkan munculnya berbagai macam perubahan dalam tatanan sosial umat Islam, baik dalam ranah politik, sosial, budaya, dan lain sebagainya. Hal tersebut karena aneka perubahan yang ada banyak melahirkan simbol-sibol sosial-kultural yang secara eksplisit tidak dimiliki oleh simbol keagamaan, atau disebabkan karena tidak diimbanginya dengan pembaharuan pemikiran keagamaan. Begitu juga masih terpakunya pemikiran fiqh klasik dengan pemahaman yang tekstual, parsial, sehingga pengajiannya tidak komprehensif dan aktual. Berkaitan dengan pemikiran fiqh tersebut, bagaimanapun pemikiran ulama bisa dipertanyakan lagi berdasarkan kriteria al-Quran dan alSunnah. Di sisi lain, pertimbangan kemaslahatan dapat dijadikan rujukan dalam upaya penyesuaian fiqh dengan zaman yang berkembang. Oleh karena itu, sebuah kajian komprehensif yang menyeluruh atas Islam diperlukan.

Harun Nasution, ${ }^{15}$ sang ilmuwan yang menjadikan filsafat sebagai landasan berfikirnya, telah melakukan pembagian ciri pemikiran Islam menjadi tiga kriteria zaman: zaman klasik (abad ke-7-12 M.), ini disebut juga dengan zaman rasional; zaman pertengahan (abad ke-13-18 M.), ini disebut dengan zaman keredupan; zaman modern (abad ke-19 M.sekarang), ini disebut dengan zaman kesadaran. Berdasarkan kriteria tersebut, fiqh klasik yang dimaksud di sini adalah pola pemahaman fiqh abad ketujuh hingga keduabelas. Sementara itu fiqh kontemporer yang dimaksud adalah fiqh abad kesembilanbelas dan seterusnya.

Metode berfikir ulama klasik banyak terkait langsung dengan al-Quran dan al-Hadits, sehingga banyak melahirkan

15 Harun Nasution, Pembaharuan dalam Islam (Jakarta: Bulan Bintang, 1975), 12-13. 
ijtihad-ijtihad yang kualitatif, hal ini banyak dicontohkan oleh para sahabat Nabi SAW., terutama Umar bin Khattab. ${ }^{16}$ Metode berfikir (manhaj al-fikri) seperti inilah yang banyak ditiru oleh para pemikir dan penggagas pemikiran dalam Islam semisal Abu Hanifah, Syafi'i, Maliki, dan Hanbali. Akan tetapi, konstruksi pemikiran semacam ini diteruskan pada abad pertengahan dengan tidak merujuk langsung kepada al-Quran dan al-Hadits, tetapi lebih merujuk pada hasil ijtihad para ulama klasik. Dengan begitu, yang terjadi adalah repetisirepetisi hasil pemikiran ulama klasik dengan sedikit modifikasi. Tidak heran jika corak berfikir tentang fiqh pada abad ini cenderung tradisional. Konstruksi pemikiran abad pertengahan ini ditentang oleh para pemikir dan ulama masa modern, mereka berslogan" kembali kepada al-Quran dan al-Hadits" (back to Quran and Sunnah).

Konstruksi pemikiran yang dilakukan oleh para pemikir modern ternyata tidak cukup memuaskan. Di satu sisi, mereka telah dapat menampilkan sebuah pola metodologis; namun di sisi lain, ternyata pemikiran mereka masih tidak komprehensif dan cenderung menafikan konstruksi nalar-nalar sebelumnya. Hal ini dapat difahami karena konstruksi nalar fikir mereka merupakan antitesis atas konstruksi pemikiran abad pertengahan, sehingga modernisme di sini dianggap tidak memiliki akar penunjang dan metodologi yang komprehensif.

Di samping itu, menurut Rahman, modernisme tidak berpijak pada tradisi. Dari sini kemudian dia mencoba memapankan konstruksi Neomodernisme-nya, yakni dengan menggali nilai-nilai substantif al-Quran. Rahman menyatakann bahwa elan vital (dorongan penting) dasar al-Quran adalah

16 Amir Nuruddin, Ijtihad Umar ibnu Khattab, Studi tentang Perubahan Hukum dalam Islam (Jakarta: Rajawali Press, 1990), 30. 
moral. ${ }^{17}$ Melalui ajaran moral, manusia diharapkan dapat mengemban tugas mulia sebagai khalifah Allah di muka bumi. Manusia bisa mengembangkan kehidupan yang sesuai dengan fitrah manusia, yaitu kehidupan yang berkeadilan, egalitarian dan penuh kesejahteraan serta berwawasan linngkungan. Secara substantif dan konstitutif, ajaran al-Quran dan alSunnah Nabi Muhammad SAW. adalah aksi dalam kehidupan manusia. ${ }^{18}$

\section{Pendidikan Islam Perspektif Fazlur Rahman}

Rahman sebagai seorang tokoh pendidikan Islam mencoba memberikan suatu harapan bagi masa depan Islam, terutama ketika dia menawarkan suatu metode yang disebut dengan "Neomodernisme Islam". Dia mencoba memberikan interpretasi baru terhadap slogan "kembali kepada al-Quran dan al-Sunnah". Hal ini disadarinya sebagai sesuatu yang berjangka panjang, dan penyebaran serta penerapannya harus dilakukan oleh kaum terdidik. Ini hanya bisa diwujudkan melalui pendidikan.

Pembaharuan pendidikan adalah satu-satunya pendekatan untuk suatu penyelesaian jangka panjang atas problem-problem yang dialami masyarakat Islam saat ini. Walaupun demikian, dia mengakui bahwa pembaharuan pendidikan tidak tercapai dalam waktu sehari atau semalam saja. Pendidikan adalah suatu proses yang paling sedikit memakai waktu dan generasi. Oleh karena itu, dia menawarkan ide berjangka, yaitu: "menciptakan orientasi politis Islam yang asli" dan "menciptakan iklim intelektual sebagai langkah awal

\footnotetext{
17 Fazlur Rahman, Islam, terj. Ahsin Muhammad (Bandung: Pustaka, 1984), 20.

18 Rafiq Zainul Mun'im, "Fazlur Rahman dan Tafsir Kontekstual”, 38. 
pengislaman seluruh segi kehidupan".19 Mengenai penciptaan iklim intelektual, menurutnya adalah hal yang mendesak, karena dalam beberapa hal, intelektualitas Islam telah mati. Kemacetan intelektual ini dibaca oleh Rahman sebagai sebab kegagalan hukum dan lembaga-lembaga syariah yang semestinya mengembangkan diri untuk memenuhi kebutuhankebutuhan masyarakat.

Munculnya faham sekularis di dunia Islam pada masa pra-modernis telah mempengaruhi jalannya Islam modern, khususnya dalam lapangan pendidikan, meski ada perbedaanperbedaan substansial dalam sifat perkembanganperkembangan modern di berbagai kawasan Muslim. Perbedaan tersebut disebabkan oleh beberapa faktor. ${ }^{20}$ Pertama, kawasan budaya tertentu tetap mempertahankan kedudukannya vis-à-vis ekspansi politik Eropa dan ia didominasi dan diperintah oleh suatu negara kolonial Eropa, baik de jure maupun de facto. Kedua, watak organisasi ulama atau kepemimpinan keagamaan, dan hubungan mereka dengan lembaga-lembaga pemerintah sebelum terjadinya penjajahan. Ketiga, keadaan perkembangan pendidikan Islam dan budaya yang menyertainya sebelum terjadinya penjajahan. Keempat, sifat kebijakan kolonial dari negara penjajah tertentu seperti Inggris, Perancis atau Belanda.

Melihat kemacetan intelektualitas Islam, Rahman menganjurkan agar pendidikan Islam dijadikan pokok kebijakan yang bersifat nasional oleh seluruh negeri-negeri Muslim, sama halnya dengan pendidikan umum dan profesional. Perhatiannya begitu serius mengaitkan antara intelektualitas dan pendidikan Islam. Baginya, antara keduanya

19 Yahya Hidayah, "Fazlur Rahman: Kiai dari Chicago", Amanah (No. 60, 21 Oktober-3 November, 1998), 60.

${ }^{20}$ Fazlur Rahman, Islam dan Modernitas..., 43. 
tidak dapat dipisahkan, karena intelektualitas Islam adalah esensi dari pendidikan tinggi Islam itu sendiri. Lebih jauh, dia menyatakan bahwa intelektualitas Islam justru merupakan kriteria untuk menilai keberhasilan atau kegagalan sebuah sistem pendidikan Islam. Intelektualitas Islam inilah yang dijadikan paradigma oleh Rahman dalam memandang pendidikan Islam. Bukan seperti yang dimaksudkan oleh kebanyakan pemikir konvensional, yang memandang pendidikan Islam hanya sebagai perlengkapan dan peralatanperalatan fisik atau kuasi-fisik pengajaran seperti buku-buku yang diajarkan maupun struktur eksternal pendidikan. ${ }^{21}$

Anjuran untuk menasionalkan bahkan menginternasionalkan kebijakan pendidikan Islam dilontarkan Rahman dengan mempertimbangkan bahwa sekolah-sekolah khusus agama masih merupakan sisa-sisa sistem pendidikan pra modern. Menurutnya, mereka dikhususkan hanya sebagai suatu akibat diferensiasi dan pemisahan dari suatu sistem pendidikan modern. Akan tetapi sistem pendidikan modern pun tidak menjamin sistem pendidikan tradisional itu menjadi suatu monopoli pendidikan agama, tidak pula sistem pendidikan tradisional itu melepaskan tuntutannya untuk mendidik kaum Muslimin pada umumnya.

Faktor penting dalam kegagalan mereka tersebut tampak tertumpu pada sistem pendidikan yang hampir tak memungkinkan bagi pertumbuhan ide-ide baru yang dipandang oleh Rahman akan dapat menafsirkan kembali Islam. Dalam pandangannya, baik sistem pendidikan baru maupun lama, belumlah sanggup memenuhi kebutuhan untuk melaksanakan penyesuaian dan pembaharuan secara rutin dan sistematis. Secara khusus, dia menyoroti pendidikan Islam di Indonesia. Dikatakan bahwa di negeri ini, kebijakan agama

${ }^{21}$ Fazlur Rahman, Islam dan Modernitas..., 43. 
telah mengarah ke sistem pendidikan untuk mendapatkan penyelesaian. Akan tetapi, faktor menonjol yang menyatukan Indonesia -seperti Pakistan, dan membedakannya dari negeri Islam lain, seperti Turki- bahwa hanya di dalam dua negeri ini (Indonesia dan Pakistan) telah timbul gerakan modernis Muslim (bukan sekuler) yang kuat. Dari sudut pandang kebijakan, kedudukan penting kaum modernis itu terletak pada prinsip bahwa pembaharuan agama Islam hanya mungkin melalui pendidikan ketimbang organisasi politik.

Masyarakat Islam, demikian Rahman,22 pernah dipandang sebagai suatu masyarakat yang paling kaku dan paling sulit untuk berubah dibandingkan dengan masyarakat lain. Akibatnya, terasa sekali bahwa peralihan ke masyarakat modern bagi kaum Muslimin akan lebih lama, lebih berat dan lebih tidak berkesinambungan, dan sebaliknya, lebih produktif dalam sisa-sisa penyakit sosial dan politiknya. Dia menduga kesulitan tersebut tidak terletak pada kekhususan doktrindoktrin Islam, bukan pula pada isi perintah-perintah Tuhan menurut pandangan Islam. Akan tetapi, kesulitan tersebut ada, apabila doktrin-doktrin dan perintah-perintah Tuhan itu tampak bertentangan dengan syarat-syarat mutlak masyarakat modern, sehingga kebanyakan kaum Muslimin menolak untuk diyakinkan bahwa doktrin-doktrin dan perintah-perintah itu sebenarnya tak penting bagi Islam. Dia menyesalkan keadaan yang telah menjadi sedemikian rupa sehingga banyak kaum Muslimin percaya pada dalil-dalil Islam yang bertentangan dengan dunia modern, itu dianggap ajaran-ajaran terpenting bagi mereka.

Secara umum, Rahman meyakinkan bahwa kekacauan dan ketidakselerasan dunia Islam dengan dunia modern disebabkan oleh pemahaman yang tidak seimbang terhadap

${ }^{22}$ Fazlur Rahman, Islam dan Modernitas ..., 43. 
ajaran-ajaran al-Quran. Oleh Sebab itu, dia mencurahkan perhatiannya pada pembaharuan pendidikan dan revivalisasi penafsiran Islam (ijtihad) melalui tulisan-tulisan dan pengajaran-pengajarannya.

Dalam pandangan Rahman, terdapat beberapa problem yang dihadapi oleh pendidikan Islam, antara lain sebagai berikut.

\section{Permasalahan Pendidikan Islam}

Pendidikan Islam selalu dihadapkan pada tantangan yang jauh lebih berat dari tantangan yang dihadapi pada masa permulaan penyebaran Islam. Tantangan tersebut berupa timbulnya aspirasi dan idealitas umat manusia yang multi-interest dan berdimensi nilai ganda dengan tuntutan hidup yang multi-kompleks, ${ }^{23}$ ditambah lagi dengan beban psikologis umat Islam dalam menghadapi mainstrem Barat. Kesulitan ini menjadi accut karena faktor psikologi lain, yang muncul akibat menjadi pihak yang kalah (berbeda dengan kedudukan internasional Islam klasik yang waktu itu umat Islam adalah pihak yang menang dan berkuasa). ${ }^{24}$

Hal tersebut di atas, menurut Syed Sajjad Husain dan Syed Ali Ashraf, ${ }^{25}$ telah menyuburkan tumbuhnya golongangolongan penekan. Golongan-golongan ini dengan cepat meraih kekuasaan dari orang-orang yang pemikirannya lebih cenderung kepada agama. Akibatnya, muncul semacam ketegangan dan pertentangan antara golongan sekuler dengan golongan agama, pertentangan ini telah

23 M. Arifin, Kapita Selekta Pendidikan: Islam dan Umum (Jakarta : Bumi Aksara,1993), 5.

24 Nurcholish Madjid, Islam, Doktrin dan Peradaban: Sebuah Telaah Kritis tentang Masalah Keimanan, Kemanusiaan dan Kemodernan (Jakarta: Paramadina, 1992), 445.

25 Syed Sajjad Husain dan Syed Ali Ashraf, Crysis in Muslim Education (Jeddah: King Abdul Aziz University, 1979), 32.

Jurnal Pendidikan Agama Islam 
menampakkan diri secara terang-terangan di beberapa negara seperti Turki, Mesir, Indonesia. Kondisi semacam ini pada gilirannya mengakibatkan pendidikan Islam tidak diarahkan kepada tujuan yang positif. Tujuan pendidikan Islam cenderung berorientasi pada kehidupan akhirat semata dan bersifat defensif.

Dalam kondisi kepanikan spiritual seperti itu, strategi pendidikan Islam yang dikembangkan di seluruh dunia Islam secara universal bersifat mekanis. Akibatnya, muncul golongan yang menolak segala sesuatu yang berbau Barat, bahkan ada yang mengharamkan pengambil-alihan ilmu dan teknologinya. ${ }^{26}$ Melihat terjadinya kegelisahan intelektualitas yang berujung pada gagalnya pencapaian substansi tujuan pendidikan Islam itu, Rahman mengajukan gagasan cemerlang sebagai solusi orientatif pendidikan Islam. Solusi tersebut dapat dilihat di bawah ini.

Pertama, tujuan pendidikan Islam yang hanya bersifat defensif dan cenderung berorientasi kepada kehidupan akhirat saja harus segera dirubah. Tujuan pendidikan Islam harus diorientasikan kepada kehidupan dunia dan akhirat. Rahman ${ }^{27}$ menyatakan, bahwa tujuan pendidikan dalam pandangan al-Quran adalah untuk mengembangkan kemampuan inti manusia dengan cara sedemikian rupa sehingga seluruh ilmu pengetahuan yang diperolehnya akan menyatu dengan kepribadian kreatifnya.

Kedua, Beban psikologis umat Islam dalam menghadapi Barat harus segera dihilangkan. Untuk menghilangkan beban psikologis umat Islam tersebut, Rahman menganjurkan agar dilakukan kajian Islam yang menyeluruh secara historis dan

${ }^{26}$ A. Syafi'i Ma'arif, Peta Bumi intelektual Islam di Indonesia (Bandung: Mizan, 1993), 145.

27 Taufiq Adnan Amal, Islam dan Tantangan Modernitas..., 133. 
sistematis mengenai perkembangan disiplin-disiplin ilmu Islam seperti teologi, hukum, dan lain sebagainya, dengan berpegang kepada al-Quran.

Ketiga, Sikap negatif umat Islam terhadap ilmu pengetahuan juga harus dirubah. Menurut Rahman, tidak ada yang salah dalam ilmu pengetahuan, yang bisa salah adalah penggunanya. Dalam pandangan Islam, mencari ilmu merupakan suatu bentuk ibadah yang mendorong manusia untuk menjalin hubungan yang lebih dekat dengan Allah SWT. Oleh karenanya, ilmu tidak boleh disalahgunakan untuk merusak iman dan moral serta mendatangkan bahaya dan kehancuran. Menurut Rahman, Islam membolehkan umatnya untuk memperoleh ilmu pengetahuan dalam bentuk apapun, selama ilmu pengetahuan yang diperolehnya tersebut tidak menyesatkan dan mengarahkan pada penghancuran diri dan sesama. Ilmu pengetahuan, pada hakikatnya harus dimanfaatkan untuk tujuan yang sehat bagi individu atau kolektif.

\section{Dikotomi Pendidikan Islam}

Pendidikan Islam masih terasa memprihatinkan, salah satunya adalah masih terasa adanya dikotomi ilmu agama dan ilmu umum. Masih dikenal, bahkan diyakini, adanya sistem "pendidikan agama" dan "pendidikan umum". Kedua sistem tersebut juga dikenal dengan sebutan "pendidikan tradisional" -untuk yang pertama, dan "pendidikan modern" -untuk yang kedua. ${ }^{28}$ Semestinya, hal ini tidak boleh terjadi karena dikotomi pendidikan Islam hanya merupakan manifestasi sistem pendidikan Barat yang dinasionalisasikan dengan menambah beberapa mata pelajaran agama Islam

28 Mastuhu, Memberdayakan Sistem Pendidikan Islam (Jakarta: Ciputat Press, 2002), 3.

Jurnal Pendidikan Agama Islam 
dan sistem pendidikan Islam yang berasal dari zaman klasik (tradisional) yang tidak diperbaharui secara mendasar, yang mempunyai arah yang berbeda atau dalam beberapa sisi penting justru bertolak belakang. ${ }^{29}$

Persoalan dikotomi pendidikan itu telah melanda seluruh negara Muslim atau negara yang mayoritas penduduknya beragama Islam. Menurut Husain dan Ashraf, ${ }^{30}$ dikotomi pendidikan itu bukan hanya menyangkut perbedaan dalam struktur luarnya saja tetapi juga perbedaan yang lahir dari pendekatan mereka terhadap tujuan-tujuan pendidikan.

Sistem tradisional atau klasik Islam didasarkan atas seperangkat nilai yang berasal dari al-Quran. Di dalam alQuran dinyatakan bahwa tujuan-tujuan pendidikan yang sesungguhnya adalah menciptakan manusia yang taat kepada Tuhan dan akan selalu berusaha untuk patuh pada perintah-perintah Tuhan. Sementara itu, sistem pendidikan modern, yang secara khusus mengesampingkan Tuhan, berusaha untuk tidak melibatkan Tuhan dalam penjelasannya mengenai asal-usul alam raya atau fenomena bagaimana manusia selalu berhubungan setiap harinya dengan Tuhan. Akibatnya, hal ini menghasilkan manusia yang dikaruniai rasa ketaatan yang besar -di satu pihak, dan melahirkan sosok manusia yang beranggapan bahwa tidak ada batasan atau akhir dari kemungkinan-kemungkinan di dalam dirinya, atau dapat membentuk sendiri kehidupan yang dijalaninya tanpa tuntutan ilahi -di pihak lain.

Di tengah maraknya persoalan dikotomi model pendidikan Islam tersebut di atas, Rahman berupaya

29 Muslih Usa (Ed.), Pendidikan Islam di Indonesia: Antara Cita dan Fakta (Yogyakarta: Tiara Wacana, 1991), 3.

30 Syed Sajjad Husain dan Syed Ali Ashraf, Crysis in Muslim Education..., 56. 
menawarkan sebuah solusi. Menurutnya, untuk menghilangkan dikotomi sistem pendidikan Islam adalah dengan cara mengintegrasikan antara ilmu-ilmu agama dengan ilmu-ilmu umum secara organis dan menyeluruh. Mengingat, pada dasarnya ilmu pengetahuan itu terintegrasi dan tidak dapat dipisah-pisahkan. Adanya keseimbangan antara ilmu-ilmu agama (akhirat) dan umum (dunia) dalam suatu kurikulum pendidikan Islam, menurut Hasan Langgulung, pada gilirannya akan melahirkan spesialisasi pada bagian ilmu sesuai dengan periode perkembangan dan tingkat pendidikan. ${ }^{31}$

Bagi Rahman, ilmu pengetahuan itu pada prinsipnya adalah satu yaitu berasal dari Allah SWT. Hal ini sesuai dengan apa yang dijelaskan dalam al-Quran. Menurut alQuran, semua pengetahuan datangnya dari Allah SWT., sebagian diwahyukan kepada orang yang dipilih-Nya melalui ayat-ayat Quraniyah dan sebagaian lagi melalui ayat-ayat kauniyah yang diperoleh manusia dengan menggunakan indera, akal dan hatinya. Pengetahuan yang diwahyukan mempunyai kebenaran absolut, sedangkan pengetahuan yang diperoleh atau dicari, kebenarannya tidak mutlak.

\section{Peserta Didik, Pendidik dan Sarana Pendidikan}

\section{a. Peserta Didik}

Peserta didik yang dihadapi oleh dunia pendidikan Islam di negara-negara Islam terkait erat dengan belum berhasilnya penyelesaian dikotomi antara ilmu-ilmu agama dan ilmu-ilmu umum di lembaga-lembaga pendidikan Islam. Belum tuntasnya penghapusan dikotomi antara ilmu-ilmu agama dan ilmu-ilmu umum

31 Hasan Langgulung, Asas-Asas Pendidikan Islam (Jakarta: Pustaka al-Husna, 1992), 117. 
mengakibatkan rendahnya kualitas intelektual peserta didik dan munculnya pribadi-pribadi yang pecah (split personality). Kondisi tersebut pada gilirannya akan menimbulkan moralitas ganda (double morality) di kalangan umat Islam. Ironisnya, dikotomi pendidikan Islam telah mengakibatkan tidak lahirnya peserta didik yang memiliki komitmen spiritual dan intelektual yang mendalam terhadap Islam. Sebagian mereka lebih berperan sebagai pemain-pemain teknis dalam masalahmasalah agama; sementara ruh agama jarang digumulinya secara intens.

Menurut Rahman, ada beberapa usaha yang harus dilakukan untuk mengatasi masalah tersebut di atas. Pertama, peserta didik harus diberikan pelajaran alQuran melalui metode-metode yang mengondisikan kitab suci bukan hanya dijadikan sebagai sumber inspirasi moral tapi juga dapat dijadikan sebagai rujukan tertinggi untuk memecahkan masalah-masalah dalam kehidupan sehari-hari yang semakin kompleks dan menantang. Dalam kaitan itu Rahman menawarkan metode sistematisnya dalam memahami dan menafsirkan alQuran. Metode itu terdiri dari dua gerakan ganda yaitu dari situasi sekarang ke masa al-Quran diturunkan dan kembali lagi ke masa kini. ${ }^{32}$

Gerakan pertama mempunyai dua langkah. Satu, orang harus memahami arti atau makna dari suatu pernyataan dengan mengkaji situasi dan problem historis dimana pernyataan al-Quran tersebut merupakan

32 Fazlur Rahman, "Recommendation of the Improvement of IAIN and Instruction Submitted to the Minister of Religious Affair, His Excellence, Munawir Sadjali, MA," dalam Muhammad Wahyu Nafis (Ed.), Kontekstualisasi Ajaran Islam 70 Tahun Prof. Dr. Munawir Sadjali, MA (Jakarta: Paramadina, 1995), 521. 
jawaban. Dua, menggeneralisasikan jawaban-jawaban spesifik tersebut dan menyatakannya sebagai pernyataan-pernyataan yang memiliki tujuan moral dan sosial umum, yang dapat disaring dari ayat-ayat spesifik dalam sinaran latar belakang sosio-historis yang sering dinyatakan. Menurut Rahman, jika dua gerakan ganda ini dapat dicapai, perintah-perintah al-Quran akan hidup dan efektif kembali. Metode penafsiran yang ditawarkan Rahman itulah yang disebut sebagai prosedur ijtihad. Kedua, memberikan materi disiplin ilmu-ilmu Islam secara historis, kritis dan holistik kepada peserta didik. Disiplin ilmu-ilmu Islam itu meliputi teologi, hukum, etika, ilmu-ilmu sosial, filsafat, dan ilmu-ilmu alam.

\section{b. Pendidik}

Pendidik dalam perspektif Islam mempunyai peranan yang sangat penting di dalam proses pendidikan. Dialah yang bertanggung jawab terhadap perkembangan peserta didik dengan mengupayakan perkembangan seluruh potensi, baik kognitif, afektif, maupun psikomotorik. ${ }^{33}$ Untuk mendapatkan kualitas pendidik seperti itu, di lembaga-lembaga pendidikan Islam cukup sulit. Hal ini dibuktikan Rahman melalui pengamatannya terhadap perkembangan pendidikan Islam di beberapa negara Islam. Dia melihat bahwa pendidik yang berkualitas dan profesional serta memiliki pemikiran-pemikiran yang kreatif dan terpadu yang mampu menafsirkan hal-hal yang lama dalam bahasa yang baru sebagai alat yang berguna untuk idealitas masih sulit ditemukan pada masa

33 Ahmad Tafsir, Ilmu Pendidikan dalam Perspektif Islam (Bandung: Remaja Rosdakarya,1992), 49. 
modern. Masalah kelangkaan tenaga pendidik berkualitas seperti ini telah melanda hampir semua negara Islam.

Dalam mengatasi kelangkaan tenaga pendidik seperti itu, Rahman menawarkan gagasan sebagai berikut. ${ }^{34}$ Pertama, merekrut dan mempersiapkan peserta didik yang memiliki bakat-bakat terbaik dan mempunyai komitmen yang tinggi terhadap lapangan agama (Islam). Kedua, mengangkat lulusan madrasah yang relatif cerdas atau menunjuk sarjana-sarjana modern yang telah memperoleh gelar doktor di universitas-universitas Barat dan telah berada di lembaga-lembaga keilmuan tinggi sebagai guru besar-guru besar pada bidang studi bahasa Arab dan bahasa Persi serta sejarah Islam.

Ketiga, para pendidik harus dilatih di pusat-pusat studi keislaman di luar negeri, khususnya di Barat. Keempat, mengangkat beberapa lulusan madrasah yang memiliki pengetahuan bahasa Inggris dan mencoba melatih mereka dalam teknik riset modern dan sebalikmya menarik para lulusan universitas bidang filsafat dan ilmu-ilmu sosial dengan memberi mereka pelajaran bahasa Arab dan disiplin-disiplin Islam klasik seperti Hadits dan yurisprudensi Islam. Kelima, menggiatkan para pendidik untuk melahirkan karyakarya keislaman secara kreatif dan memiliki tujuan demi cita-cita Islam.

\section{c. Sarana Pendidikan}

Pentingya sarana pendidikan sudah diketahui oleh banyak tokoh Islam. Sarana pendidikan seperti perpustakaan memberikan saham yang besar bagi peningkatan kualitas lembaga pendidikan dan intelektual

34 Fazlur Rahman, Islam dan Modernitas. 
umat Islam. Secara historis, Islam memiliki perpustakaan dalam tiga (3) kategori. Pertama, perpustakaan umum yang biasanya merupakan bagian dari masjid, madrasah, atau lembaga-lembaga pendidikan lainnya. Perpustakaan ini terbuka untuk siapa saja yang ingin menggunakan koleksinya. Masuk dalam golongan jenis perpustakaan ini, antara lain adalah Bait al-Hikmah, Dar al-Hikmah, dan Dar al-Ilmi.

Kedua, perpustakaan semi-umum yang hanya terbuka untuk kalangan tertentu saja, biasanya hanya untuk para ilmuwan terkenal dan bangsawan. Seringkali perpustakaan jenis ini terdapat di lingkungan istana. Masuk dalam jenis perpustakaan ini, antara lain adalah perpustakaan Naser li Dinillah, perpustakaan Mu'tashim, dan perpustakaan Fathimiyyin. Ketiga, perpustakaan pribadi yaitu perpustakaan milik individu, baik sarjana maupun orang yang mengumpulkan buku sebagai kesenangan semata. Hampir semua kota utama Islam dihiasi dengan perpustakaan besar yang melayani semangat ilmiah masyarakat sekitarnya.

Tiga model perpustakaan yang ditinggalkan oleh umat Islam itu telah meninggalkan pengaruh yang besar dalam perputaran roda pendidikan dan pengajaran serta mendorong para peserta didik untuk melanjutkan karya ilmiahnya. Dalam pengamatan Rahman,35 di beberapa negara Islam yang dikunjunginya, menunjukkan bahwa keadaan perpustakaan di lembaga-lembaga pendidikan Islam tersebut masih belum memadai, terutama jumlah buku-bukunya. Buku-buku yang tersedia di perpustakaan lembaga-lembaga pendidikan Islam masih sangat minim jumlahnya, terutama buku-buku yang berbahasa Arab

35 Fazlur Rahman, Islam dan Modernitas, 123.

Jurnal Pendidikan Agama Islam

Volume 02 Nomor 02 November 2014

Hal $294-298$ 
dan berbahasa Inggris. Untuk mengatasi masalah tersebut, dia mengusulkan agar fasilitas perpustakaan harus dilengkapi dengan buku-buku yang berbahasa Arab dan berbahasa Inggris.

\section{Penutup}

Dari pemaparan di atas, dapat dikatakan bahwa ide-ide Rahman mengenai pendidikan Islam termasuk dalam kategori kontekstual. Ini menunjukkan bahwa dalam mengemukakan ide-idenya, Rahman mendasarkannya pada pengalaman empirik dan pengamatan yang realistis. Oleh karena itu, tidaklah basi jika menerapkan ide-ide Rahman dalam konteks pendidikan Islam dewasa ini. Pisau analisis yang dipakai Rahman dalam mengkaji pendidikan Islam pada masanya, kiranya dapat dipakai sebagai pisau analisis dalam mengkaji pendidikan Islam kontemporer. Meski begitu, karena masa hidup Rahman berbeda dengan masa hidup umat Islam sekarang -dalam konteks sosial, maka perlu diberikan nilai kritis-transformatif bagi ide-ide Rahman sebelum diterapkan dalam konteks kekinian.

Rahman terkenal sebagai tokoh neo-modernisme karena berusaha melakukan modernisasi pendidikan Islam dengan tidak melupakan warisan klasik umat Islam. Dia mengusulkan bahwa orientasi pendidikan Islam harus mengarah kepada kebutuhan di dunia dan akhirat. Dia juga tidak setuju dengan adanya dikotomi ilmu agama dan umum. Harus ada upaya integrasi antara ilmu agama dan umum, karena pada dasarnya ilmu itu utuh dan bersumber dari Allah SWT. Dia juga menyarankan agar ada upaya peningkatan kualitas pendidik Muslim, perhatian khusus terhadap peserta didik yang berbakat, dan pemenuhan sarana prasarana pendidikan yang memadai. 
Muhammad Fahmi

\section{DAFTAR PUSTAKA}

Al-Faruqi, Ismail Raji, 1984, Islamisasi Ilmu Pengetahuan: PrinsipPrinsip dan Rencana Kerja, terj. Anas Mahyudin (Bandung: Pustaka).

Al-Maududi, Abu A’la, 1991, Manhaj Jadid li Tarbiyah wa Ta'lim, terj. Judi al-Falasani (Solo: CV. Ramadani).

Al-Nahlawi, Abdurrahman, Ushul al-Tarbiyah al-Islamiyyah wa Asalibuha (Damsyik: Dar al-Fikr).

Al-Jamali, Fadlil, 1988, Menerabas Krisis Pendidikan Dunia Islam, terj. Muzayin Arifin (Jakarta: Golden Terayon Press).

Al-Attas, Syed Muhammad al-Nuqaib, 1981, Islam dan Sekularisme, terj. Karsidjo Djojosuwarno (Bandung: Pustaka).

1979, Aims and Objective of Islam Education (Jeddah:

King Abdul Azis University).

Al-Abrasyi, Muhammad Athiyah, 1970, Al-Tarbiyah al-Islamiyah (Mesir: Dar al-Fikr).

Amal, Taufiq Adnan, 1993, Islam dan Tantangan Modernitas: Studi atas Pemikiran Hukum Fazlur Rahman, Cet. Ke-4 (Bandung: Mizan).

Amiruddin, M. Hasbi, 2000, Konsep Negara menurut Fazlur Rahman (Yogyakarta: UII Press).

Arifin, M., 1993, Kapita Selekta Pendidikan: Islam dan Umum (Jakarta : Bumi Aksara).

Azhar, M., 1996, Fiqih Kontemporer dalam Pandangan Neomodernisme Islam (Yogyakarta: Pustaka Pelajar).

Husein, Machnun, 1983, Pendidikan Islam dalam Lintasan Sejarah (Yogyakarta: Nur Cahaya).

Hidayah, Yahya, 1998, "Fazlur Rahman: Kiai dari Chicago", Amanah (No. 60, 21 Oktober-3 November).

Husain, Syed Sajjad dan Syed Ali Ashraf, 1979, Crysis in Muslim Education (Jeddah: King Abdul Aziz University). 
Langgulung, Hasan, 1980, Beberapa Pemikiran tentang Pendidikan Islam (Bandung: Al-Ma'arif).

1992, Asas-Asas Pendidikan Islam (Jakarta: Pustaka alHusna).

Mun'im, Rafiq Zainul, 2005, "Fazlur Rahman dan Tafsir Kontekstual", Wacana (Surabaya: Kopertais IV, Edisi Maret).

Madjid, Nurcholish, 1992, Islam, Doktrin dan Peradaban: Sebuah Telaah Kritis tentang Masalah Keimanan, Kemanusiaan dan Kemodernan (Jakarta: Yayasan Wakaf Paramadina).

Ma'arif, A. Syafi'i, 1993, Peta Bumi intelektual Islam di Indonesia (Bandung: Mizan).

Mastuhu, 2002, Memberdayakan Sistem Pendidikan Islam (Jakarta: Ciputat Press).

Nasution, Harun, 1975, Pembaharuan dalam Islam (Jakarta: Bulan Bintang).

Nuruddin, Amir, 1990, Ijtihad Umar ibnu Khattab, Studi tentang Perubahan Hukum dalam Islam (Jakarta: Rajawali Press).

Rahman, Fazlur, 1985, Islam dan Modernitas: Tentang Transformasi Sosial, terj. Ahsin Muhammad (Bandung: Pustaka).

1984, Islam, terj. Ahsin Muhammad (Bandung: Pustaka).

, "Recommendation of the Improvement of IAIN and Instruction Submitted to the Minister of Religious Affair, His Excellence, Munawir Sadjali, MA," dalam Muhammad Wahyu Nafis (Ed.), Kontekstualisasi Ajaran Islam 70 Tahun Prof. Dr. Munawir Sadjali, MA (Jakarta: Paramadina, 1995).

Tafsir, Ahmad, 1992, Ilmu Pendidikan dalam Perspektif Islam (Bandung: Remaja Rosdakarya). 
Muhammad Fahmi

Usa, Muslih (Ed.), 1991, Pendidikan Islam di Indonesia: Antara Cita dan Fakta (Yogyakarta: Tiara Wacana). 